\title{
Exogenous Application of Harpin Protein Hpa1 onto Pinellia ternata Induces Systemic Resistance Against Tobacco Mosaic Virus
}

\author{
Defu Wang, ${ }^{1}$ Baoxia Wang, ${ }^{1}$ Jiangran Wang, ${ }^{1}$ Shuting Wang, ${ }^{1}$ Weiyu Wang, ${ }^{2}$ and Yanbing Niu ${ }^{1, \dagger}$ \\ ${ }^{1}$ College of Life Sciences, Shanxi Agricultural University, Taigu 030801, Shanxi, China \\ ${ }^{2}$ Rongcheng Plant Protection Station, Rongcheng 264300, Shandong, China \\ Accepted for publication 4 March 2020.
}

ABSTRACT

\begin{abstract}
The harpin protein Hpal has various beneficial effects in plants, such as promoting plant growth and inducing pathogen resistance. Our previous study found that Hpal could significantly alleviate the mosaic symptoms of tobacco mosaic virus (TMV) in Pinellia ternata, indicating that Hpa1 can effectively stimulate resistance. Here, the potential mechanism of disease resistance and field applicability of Hpa 1 against TMV in P. ternata were further investigated. The results showed that $15 \mu \mathrm{g} \mathrm{ml}^{-1} \mathrm{Hpal}$ had stronger antiviral activity than the control, and its protective effect was better than its curative effect. Furthermore, Hpal could significantly induce an increase in defense-related enzyme activity, including polyphenol oxidase, peroxidase, catalase, and superoxide dismutase, as well as increase the expression of disease resistance-related genes (PR1, PR3, PR5, and PDF1.2).
\end{abstract}

Concurrently, Hpa1 significantly increased the content of some disease resistance-related substances, including hydrogen peroxide, phenolics, and callose, whereas the content of malondialdehyde was reduced. In addition, field application analysis demonstrated that Hpa1 could effectively elicit a defense response against TMV in $P$. ternata. Our findings propose a mechanism by which Hpal can prevent TMV infection in Pinellia by inducing systemic resistance, thereby providing an environmentally friendly approach for the use of Hpal in large-scale applications to improve TMV resistance in Pinellia.

Keywords: biological control, disease control and pest management, virology
The dry tuber of perennial plant Pinellia ternata (Thunb.) Makino is an important raw material for traditional Chinese medicinal preparations. The tuber has antitumor properties, improves cardiovascular function, relieves cough, and elicits antifertility effects (Zuo et al. 2019). The continuous development and utilization of $P$. ternata in medicine and healthcare has resulted in increased demand, leading to its large-scale cultivation in China. In nature, $P$. ternata is mainly propagated asexually by the root tuber. During long-term asexual reproduction, viral diseases have become increasingly problematic in $P$. ternata. Our preliminary investigations revealed that several $P$. ternata plantations are infected by tobacco mosaic virus (TMV), with some fields being infected by multiple viruses, which severely affects the yield and quality of $P$. ternata. It is widely accepted that the long and slow breeding cycle of disease-resistant varieties cannot match the rapid evolution of variability in pathogens, thus limiting the effectiveness of traditional breeding approaches (Dodds and Rathjen 2010). Thus, the control of viral diseases through traditional breeding remains a challenge. The antiviral treatment of $P$. ternata might offer an alternative to traditional methods. The use of broad-spectrum resistance may limit the rapid evolution of pathogen populations and effectively control viral diseases. For instance, the expression of broad-spectrum elicitors isolated from some fungi and bacteria, such as ningnanmycin (Han et al. 2014), sulfated lentinan (Wang et al. 2013a), esterified lactoferrin (Wang et al. 2013b), GJ-22 (Su

†Corresponding author: Y.-B. Niu; niuyanbingbest@163.com

First and second authors contributed equally to this work and should be considered co-first authors.

Funding: This study was supported by the National Natural Science Foundation of China (31601612 and 31772130), China Agriculture Research System (CARS-21), and Natural Science Foundation of Shanxi Province of China (201701D221159).

The author(s) declare no conflict of interest.

(C) 2020 The American Phytopathological Society et al. 2017), and GP1 (Zhang et al. 2016), have been shown to confer enhanced resistance against TMV in tobacco.

Effective resistance can also be triggered by specific broadspectrum defense response elicitors, such as the harpin proteins produced by Gram-negative plant pathogenic bacteria. Harpins are multifunctional proteins that induce plant growth and defense responses (Alfano and Collmer 2004; Kim et al. 2003; Wei et al. 1992). They are environmentally friendly and conform to good agricultural practice for Chinese crude drugs, and therefore have a great potential for practical use in Chinese traditional medicine. One well-characterized harpin protein, Hpa1, is produced by Xanthomonas oryzae, which is an important bacterial leaf streak pathogen of rice (Zhu et al. 2000). Like all harpin orthologs identified in different species of Gram-negative plant pathogenic bacteria (Dong et al. 1999; He et al. 1993; Kim and Beer 2000; Liu et al. 2006; Wei et al. 1992), Hpa1 induces plant growth and defense responses (Chen et al. 2008a, b; Liu et al. 2006; Peng et al. 2004; Wu et al. 2007; Zhang et al. 2007; Zhang et al. 2011). The transgenic expression of the Hpal gene in plants can enhance disease resistance against various pathogens (Huo et al. 2010; Jang et al. 2006; Peng et al. 2004; Ren et al. 2006a, b; Sohn et al. 2007; Shao et al. 2008). For instance, the expression of Hpal in rice plants enhanced resistance to rice bacterial blight and stem rot of rice sclerotium (Ren et al. 2006a, b), while Hpal expression in wheat improved resistance to gibberellic disease and powdery mildew ( $\mathrm{Li}$ et al. 2014; Wang et al. 2014). In addition, disease resistance can also be induced by the external application of Hpa1 to plants (Chen et al. 2008a, b; Sang et al. 2012), which results in improved plant growth with increased disease resistance (Chen et al. 2008a, b). The above findings suggest that $\mathrm{Hpa} 1$ is a desired agricultural agent that enhances plant growth and defense responses with little cost to plant development (Chen et al. 2008a, b; Peng et al. 2004; Wu et al. 2007).

Numerous methods have been proposed for the prevention of TMV (Chen et al. 2008a, b; Durrant and Dong 2004; Li et al. 2011; Ryals et al. 1996; Su et al. 2017; Wang et al. 2013; Zhao et al. 2015; Zhang et al. 2016). In particular, Hpal-expressing tobacco plants repress infection by TMV and alleviate the hypersensitive cell death 
(HCD) caused by the virus, which is a defensive response with a developmental cost (Dangl et al. 1996; Peng et al. 2004; Yu et al. 1998). Furthermore, in our previous study, we found that exogenous application of Hpal could significantly alleviate mosaic symptoms of TMV in susceptible $P$. ternata, and the TMV-CP expression level in systemic leaves was also significantly decreased. In the present study, the underlying mechanism of disease resistance and the field applicability of Hpa1 against TMV in $P$. ternata were further examined. The results showed that exogenous application of Hpal significantly enhanced the immune defense response in $P$. ternata and induced systemic resistance to TMV. Our findings provide an environmentally friendly approach for the use of Hpal in large-scale application to improve TMV resistance in Pinellia.

\section{MATERIALS AND METHODS}

Materials. Previously produced virus-free plants of $P$. ternata were used in this study for investigating the potential use of Hpal in preventing TMV infection. The healthy virus-free plants were kept in a growth chamber at $25^{\circ} \mathrm{C}$ with a light/dark period of $16 \mathrm{~h} / 8 \mathrm{~h}$ and 70 to $80 \%$ relative humidity for several days prior to use in this study. Ningnanmycin (8\%) was purchased from Deqiang Biology Co., Ltd. (Harbin, China).

Virus purification. Leaves of $P$. ternata exhibiting mosaic symptoms were collected from Xinjiang County in Shanxi Province, China in 2015. Using small RNA deep sequencing, we confirmed that only TMV was present in the virus-infected leaves. These TMV-infected $P$. ternata leaves were then used for TMV extraction and purification as previously described (Gooding and Hebert 1967). Briefly, TMV-infected leaves were homogenized in a mortar in 0.2 mol liter $^{-1}$ of phosphate buffer ( $1 \% \beta$-mercaptoethanol; 0.01 mol liter $^{-1}$ of EDTA-Na, $\mathrm{pH}$ 7.4) and filtered through gauze. The supernatant was treated with n-butanol (25:1, vol/vol), mixed, and centrifuged for $30 \mathrm{~min}$ at $1,000 \times g$. Next, the supernatant was treated with polyethylene glycol 6,000 at a final concentration of $4 \%$ until the mixture was sufficiently dissolved, incubated at $4^{\circ} \mathrm{C}$ for $1 \mathrm{~h}$, and then centrifuged for $30 \mathrm{~min}$ at $10,000 \times$ $g$. The pellet was suspended in $0.01 \mathrm{~mol} \mathrm{liter}^{-1}$ of phosphate buffer (pH 7.4), followed by differential centrifugation for $150 \mathrm{~min}$ at $60,000 \times g$ and then $5 \mathrm{~min}$ at $10,000 \times g$. Following resuspension in 0.01 mol liter $^{-1}$ of phosphate buffer ( $\left.\mathrm{pH} 7.4\right)$, the precipitate was centrifuged for $10 \mathrm{~min}$ at $1,000 \times g$. The supernatant containing TMV was collected and stored at $4{ }^{\circ} \mathrm{C}$ and used as the inoculum in subsequent experiments. After suspending the precipitate in 0.01 mol liter $^{-1}$ of phosphate buffer, the absorbance was measured by an enzyme-labeled instrument (Thermo 354, U.S.A.), and the concentration of the virus was calculated using the following formula:

$$
\text { Virus concentration }=\frac{\left(\mathrm{A}_{260} \times \text { dilution ratio }\right)}{\mathrm{E}_{260 \mathrm{~nm}}^{0.1 \%} 1 \mathrm{~cm}}
$$

Hpa1 preparation. The Hpal gene (GenBank accession number AY875714) was cloned from strain RS105 of X. oryzae pv. oryzicola genomic DNA by PCR using specific primers that contained the EcoRI and HindIII restriction sites at the 5' and 3' ends, respectively. The PCR product was confirmed by direct sequencing and was inserted into pET30a (+) (TaKaRa Biotechnology Co., Ltd., Dalian, China) between the EcoRI and HindIII sites. Then, the recombinant plasmid pET30a (+) containing the Hpa1 open reading frame sequence was transformed into Escherichia coli strain BL21 (DE3) for protein expression, and Hpa1 protein extraction and purification were performed in accordance with Dong et al. (1999).

Anti-TMV assay of Hpa1. Hpal and Ningnanmycin $(8 \%)$ were diluted with water at concentrations of 10, 15,20, and 30, and
50 and $500 \mu \mathrm{g} \mathrm{ml} \mathrm{m}^{-1}$, respectively, and used to determine the protective and curative effects by bioassay in accordance with the method described by Zhang et al. (2016). Briefly, for the protective assay, whole $P$. ternata plants were sprayed with different concentrations of Hpal solution $\left(10,15,20,30\right.$, and $50 \mu \mathrm{g} \mathrm{ml}^{-1}$ ) until the solution was dripping from the leaves, and TMV $(15 \mu \mathrm{g}$ $\mathrm{ml}^{-1}$ ) was inoculated onto one leaf from each $P$. ternata plant at 1 day postapplication (dpa). Plants treated with distilled water and ningnanmycin $\left(500 \mu \mathrm{g} \mathrm{ml}^{-1}\right)$ were used as negative and positive controls, respectively. The treated plants were incubated in a growth chamber at $25^{\circ} \mathrm{C}$ for 2 weeks, and the concentration of TMV in the upper noninoculated leaves of $P$. ternata was determined by a TMV enzyme-linked immunosorbent assay kit (Jianglai Biological Co., Ltd., Shanghai, China). For the curative assay, one plant leaf was inoculated with TMV $\left(15 \mu \mathrm{g} \mathrm{ml}^{-1}\right)$, and Hpal $(10,15,20,30$, and $50 \mu \mathrm{g} \mathrm{ml}^{-1}$ ) was sprayed onto the whole plant at 1 day postinoculation (dpi). The inhibition rates of ningnanmycin and Hpal were calculated using the following formula: Inhibition rate $(\%)=$ $[(\mathrm{C}-\mathrm{T}) / \mathrm{C}] \times 100 \%$, where $\mathrm{C}$ is the mean viral concentration in the control group, and $\mathrm{T}$ is the mean viral concentration in the treated group. TMV concentration was calculated by the standard curve with the $\mathrm{A}_{405}$ value of TMV at concentrations of $8,4,2,1,0.5,0.25$, and $0.125 \mu \mathrm{g} \mathrm{ml}^{-1}$. All assays were performed in triplicate with at least five plants per replicate.

Measurement of defense-related enzyme activity and defense-related substance content. The leaf tissues of $P$. ternata were sprayed with Hpal solution $\left(15 \mu \mathrm{g} \mathrm{ml} \mathrm{m}^{-1}\right)$, and TMV $\left(15 \mu \mathrm{g} \mathrm{ml}^{-1}\right)$ was inoculated onto $P$. ternata leaves at $1 \mathrm{dpa}$, after which the treated leaves were collected to determine the polyphenol oxidase (PPO), peroxidase (POD), catalase (CAT), and superoxide dismutase (SOD) activities and malondialdehyde (MDA) content at $0,2,4,6,8$, and $10 \mathrm{dpi}$, as well as to identify the hydrogen peroxide $\left(\mathrm{H}_{2} \mathrm{O}_{2}\right)$ content at $0,3,6,9,12,24,48,72$, and $96 \mathrm{~h}$ postinoculation (hpi). The treatment for ningnanmycin and distilled water were compared. The crude enzyme solution was extracted in accordance with the method of Fan et al. (2011) with a slight modification. The leaf samples $(0.1 \mathrm{~g})$ were homogenized in $1.2 \mathrm{ml}$ of phosphate buffer $(50 \mathrm{mM}, \mathrm{pH} 7.8)$ containing $1 \mathrm{mM}$ ethylenediaminetetraacetic acid (EDTA) and $1 \%$ polyvinyl pyrrolidone (PVP). After the solution was centrifuged at 12,000 rpm at $4^{\circ} \mathrm{C}$ for $20 \mathrm{~min}$, the supernatant was collected as an enzyme crude solution and stored at $-20^{\circ} \mathrm{C}$. The activities of PPO, POD, CAT, and SOD were determined as per the methods described by Aebi (1984), Fan et al. (2011), Tian et al. (2010), and Wang et al. (2013), respectively. The MDA content was measured in accordance with the method developed by Sofo et al. (2004). The $\mathrm{H}_{2} \mathrm{O}_{2}$ content was calculated using the $\mathrm{H}_{2} \mathrm{O}_{2}$ content detection kit (Solarbio, Beijing, China). Each sample was tested four times, and distilled water and ningnanmycin $\left(500 \mu \mathrm{g} \mathrm{ml}^{-1}\right)$ were used as negative and positive controls, respectively.

Histopathological observation. After Hpa1 $\left(15 \mu \mathrm{g} \mathrm{ml}{ }^{-1}\right)$ treatment, the chemiluminescence observation was performed on noninoculated leaves to determine the accumulation of $\mathrm{H}_{2} \mathrm{O}_{2}$ and the deposition of callose and phenolic compounds. The Hpal treatments were compared with those of ningnanmycin and distilled water treatments. The accumulation of callose and phenolic depositions on the leaf surface at different time points $(0,1,2,3$, $4,5,6,7$, and 8 dpi by TMV) were visualized by staining the leaves with aniline blue and Evans' blue dye in accordance with a previously described method (Lü et al. 2011; Wang et al. 2011). $\mathrm{H}_{2} \mathrm{O}_{2}$ accumulation in the leaves at $0,3,6,9,12,24,48,72$, and 96 hpi was observed by staining with $3,3^{\prime}$-diaminobenzidine hydrochloride (Xiao et al. 2003). The stained leaves were then observed and photographed under a fluorescence microscope with the excitation laser at $480 \mathrm{~nm}$ for $\mathrm{H}_{2} \mathrm{O}_{2}$ accumulation, as well as under a laser scanning confocal microscope with the excitation laser at 408 and $485 \mathrm{~nm}$ for callose and phenolic deposition detection, respectively. 
Gene expression analysis using real-time quantitative PCR (RT-qPCR). After Hpal (15 $\left.\mu \mathrm{g} \mathrm{ml} \mathrm{m}^{-1}\right)$ treatment was administered, total RNA was extracted from the upper noninoculated leaves at $0,2,4,6,8$, and $10 \mathrm{dpi}$ of TMV, and compared with the treatments of ningnanmycin and distilled water. Total RNA was extracted using a GeneJET plant RNA purification kit (ThermoFisher, Shanghai, China) in accordance with the manufacturer's instructions. A PrimeScript RT reagent kit with gDNA Eraser (TaKaRa, RR047Q) was applied to eliminate DNA in the total RNA. Two micrograms of total RNA was used to synthesize the firststrand cDNA using M-MLV (RNase $\mathrm{H}^{-}$) reverse transcription (TaKaRa). The reaction mixture was incubated for $20 \mathrm{~min}$ at $42^{\circ} \mathrm{C}$, followed by $5 \mathrm{~min}$ at $100^{\circ} \mathrm{C}$. The expression of the $P R$ genes (two SA-responsive genes: $P R I$ and $P R 5$; two JA/ET-responsive genes: $P R 3$ and $P D F 1.2$ ) was determined through the RT-qPCR method with $E F-1 a$ as an internal control. The specific primers of the $P R$ genes and EF-la are shown in Table 1. The RT-qPCR was performed using SYBR Premix Ex TaqII (TaKaRa) and a PTC-200 Real-Time PCR system (Bio-Rad, Shanghai, China) with $10 \mu \mathrm{l}$ of the reaction mixture consisting of $100 \mathrm{ng}$ of cDNA, $6.25 \mu \mathrm{l}$ of SYBR Premix Ex TaqII, $0.5 \mu \mathrm{l}$ of each primer at a concentration of $10 \mu \mathrm{mol}$ liter ${ }^{-1}$, and $2.25 \mu \mathrm{l}$ of $\mathrm{dH}_{2} \mathrm{O}$. The PCR cycling program was performed at $95^{\circ} \mathrm{C}$ for $3 \mathrm{~min}$, followed by 39 cycles at $95^{\circ} \mathrm{C}$ for $10 \mathrm{~s}$, $58^{\circ} \mathrm{C}$ for $30 \mathrm{~s}$, and $72^{\circ} \mathrm{C}$ for $20 \mathrm{~s}$. After each run, a dissociation curve was designed to confirm the specificity of the product and avoid the production of primer-dimers. The relative expression level of each target gene was calculated as the fold-change based on the comparative $2^{-\Delta \Delta C T}$ method (Livak and Schmittgen 2001). All samples were amplified in triplicate from three independent biological replicates.

Hpa1-induced TMV resistance under field conditions. After a few days of cultivation in a greenhouse, the virus-free $P$. ternata seedlings were transferred to an experimental plot. Four experimental plots and four control plots were set up, and each plot had an area of $8 \mathrm{~m}^{2}(2 \mathrm{~m} \times 4 \mathrm{~m})$ and contained 50 healthy $P$. ternata seedlings. Apart from the Hpal and water treatments, normal agricultural practices were applied to the field-grown plants without spraying any chemical pesticides.

Hpal (15 $\left.\mu \mathrm{g} \mathrm{ml}^{-1}\right)$, which had the optimum resistance inducing capacity as determined from the anti-TMV assay, was used to determine the optimal induction under field conditions. TMV $\left(15 \mu \mathrm{g} \mathrm{ml}^{-1}\right)$ was inoculated onto the leaves of $P$. ternata plants at 2 , 4, 8, and 10 dpa by Hpa1 or water. After 3 weeks of TMV inoculation, the fold-changes in the gene expression of the TMV coat protein $(\mathrm{CP})$ were measured using RT-qPCR. The TMV-CP primers are shown in Table 1 . Distilled water was used as the negative control, with three repetitions for each treatment. The disease incidence of each leaf was investigated and the associated symptoms on the Hpa1-treated plants were also photographed. The disease index was evaluated in accordance with the method described by Li et al. (2011). The disease index was evaluated by a rating scale of 0 to 4 , where $0=$ no symptoms observed; $1=$ light mottling and a few thin yellow veins; $2=$ mottling and vein clearing unevenly distributed on the leaf; 3 = mottling, leaf distortion, and stunting; and 4 = severe mottling, leaf curling, and stunting. Disease severity and biocontrol efficacy were calculated using the following formulas: Disease severity $=[\Sigma$ (number of diseased plants in this index $x$ disease index $) /($ total number of plants investigated $x$ the highest disease index $)] \times 100 \%$; Control efficiency $=[($ disease severity in the control group - disease severity in the treatment group)/(disease severity in the control group) $] \times 100 \%$.

Statistical analysis. Measurements were conducted with three or four samples at each point. Experimental data were processed in Microsoft Excel 2016 (Microsoft Corporation, Redmond, U.S.A.) and SPSS Statistics 20.0 (IBM Corp., Armonk, U.S.A.). Analysis of variance with a least significant difference test was performed for each variable, and data are expressed as mean values \pm standard error. Differences between the Hpal treatment and the controls were considered significant at $P \leq 0.05$ or 0.01 .

\section{RESULTS}

Antiviral activity of Hpa1 against TMV. The optimal concentration of Hpal for protective and curative effects was examined by exogenous application onto $P$. ternata to determine the mode of action of the antiviral activity of Hpal against TMV. Commercially available plant virucide ningnanmycin was used as a positive control. As indicated in Table 2, the inhibitory effect of Hpa1 on TMV increased and then decreased as the Hpa1 concentration increased. The curative $(55.4 \%)$ effect of Hpa1 at $15 \mu \mathrm{g} \mathrm{ml}^{-1}$ was similar to that of ningnanmycin at $500 \mu \mathrm{g} \mathrm{ml}-1$ $(53.1 \%)$, whereas the protective effect was better than that of ningnanmycin $(71.4 \%$ versus $67.7 \% ; P \leq 0.05)$. Moreover, the protective effect of Hpal was comparatively higher than the curative effect, indicating that Hpa1 might effectively prevent TMV from infecting plants rather than inhibiting already established TMV infection. Therefore, $15 \mu \mathrm{g} \mathrm{ml} \mathrm{m}^{-1} \mathrm{Hpal}$ was used in the subsequent experiments.

Effect of Hpa1 on defense-related enzyme activity. The P. ternata leaves sprayed with Hpal $\left(15 \mu \mathrm{g} \mathrm{ml}^{-1}\right)$ were collected to determine the enzymatic activities at $0,2,4,6,8$, and $10 \mathrm{dpi}$ of TMV, and the activity of Hpal was compared with that of ningnanmycin and distilled water. As shown in Figure 1, application of Hpa1 caused increased activities of PPO, POD, CAT, and SOD to varying degrees, which differed significantly from those of the distilled water treatment $(P \leq 0.05)$, but not from those of ningnanmycin $(P>$ 0.05). PPO is an important disease resistance-related enzyme and increase in PPO activity in Hpa1-treated leaves indicated that the plant had demonstrated strong disease resistance. Following Hpa1 application, the PPO activity in P. ternata increased significantly

TABLE 1. Sequences of the primer pairs used for real-time quantitative PCR amplification ${ }^{\mathrm{a}}$

\begin{tabular}{|c|c|c|}
\hline Primer names & Primer sequence $\left(5^{\prime}-3^{\prime}\right)$ & Accession number \\
\hline \multirow[t]{2}{*}{ PR1 } & F: GTTGCTTGTTTCATTACCTTTGC & $\mathrm{X} 14065$ \\
\hline & R: TTCTCATCGACCCACATTTTTAC & \\
\hline PR3 & F: TGTTTTGTTGTGTGTTTTTCCTG & X51425 \\
\hline \multirow[t]{2}{*}{ PR5 } & F: CCGAGGTAATTGTGAGACTGGAG & AY745249 \\
\hline & R: CCTGATTGGGTTGATTAAGTGCA & \\
\hline \multirow[t]{2}{*}{ PDF1.2 } & F: AGAAATATGCATGTCATAAAGTTA & T04323 \\
\hline & R: CAATGGTGGAAGCACAGAAG & \\
\hline \multirow[t]{2}{*}{ EF-1a } & F: TGTGATGTTTTTGTTCGGTCTTTAA & D63396 \\
\hline & R: TCAAAAGAAAATGCAGACAGACA & \\
\hline
\end{tabular}

Vol. 110 , No. 6,2020 
from 0 to 4 days, reaching the highest level at $4 \mathrm{dpi}$, and then decreased gradually during 4 to 10 days. The activities of PPO in Hpa1-treated P. ternata leaves were found to be higher than those in distilled water during the entire induction period (Fig. 1A). POD, CAT, and SOD are active oxygen-scavenging enzymes that are closely associated with disease resistance in plants (Sofo et al. 2004). Following Hpa1 application, the activity of POD increased gradually from 0 to $4 \mathrm{dpi}$ of TMV, peaking at $4 \mathrm{dpi}$, and then decreased gradually during 6 to $8 \mathrm{dpi}$, increasing again at $10 \mathrm{dpi}$ (Fig. 1B). The CAT activity of Hpa1-treated plants was significantly lower than that of the control plants at $2 \mathrm{dpi}$. However, at $4 \mathrm{dpi}$ the CAT activity of Hpa1-treated plants became higher than that of the control plants, ultimately reaching the highest level (Fig. 1C), which was conducive to the growth and reproduction of the virus.

TABLE 2. Protective and curative effects of Hpal against tobacco mosaic virus (TMV) ${ }^{\mathrm{a}}$

\begin{tabular}{lccc}
\hline & & & Inhibition rate $(\%)$ \\
\cline { 2 - 4 } Treatment & Concentration $\left(\mu \mathrm{g} \mathrm{ml}^{-1}\right)$ & Protective effect & Curative effect \\
\hline Hpa1 & 10 & $38.2 \pm 3^{* *}$ & $30.1 \pm 6^{* *}$ \\
& 15 & $71.4 \pm 3^{*}$ & $55.4 \pm 3$ \\
& 20 & $64.1 \pm 6^{*}$ & $43.7 \pm 4^{*}$ \\
Ningnanmycin & 30 & $55.6 \pm 5^{* *}$ & $40.0 \pm 9^{*}$ \\
\hline
\end{tabular}

a Protective effect indicates that whole Pinellia ternata plants were presprayed with Hpal $\left(10,15,20,30\right.$, and $\left.50 \mu \mathrm{g} \mathrm{ml} l^{-1}\right)$, and $\mathrm{TMV}\left(15 \mu \mathrm{g} \mathrm{ml}{ }^{-1}\right)$ was inoculated onto one leaf from each P. ternata plant at 1 day postapplication. Curative effect indicates that one leaf was inoculated with TMV $\left(15 \mu \mathrm{g} \mathrm{ml} \mathrm{l}^{-1}\right)$, and $\mathrm{Hpal}(10,15$, 20,30 , and $\left.50 \mu \mathrm{g} \mathrm{ml}^{-1}\right)$ was sprayed onto the whole plant at 1 day postinoculation. The inhibition rate $(\%)=[(\mathrm{C}-\mathrm{T}) / \mathrm{C}] \times 100 \%$, where $\mathrm{C}$ is the mean viral concentration in the control group, and $\mathrm{T}$ is the mean viral concentration in the treated group. All results are expressed as means \pm standard error; $n=3$ for all groups. *, $P \leq 0.05$, compared with ningnanmycin. **, $P \leq 0.01$, compared with ningnanmycin.

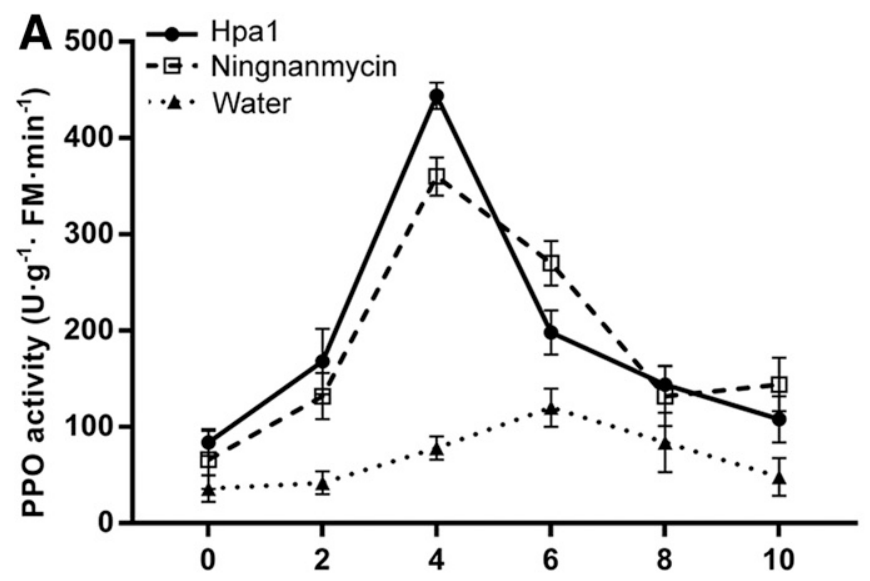

Time after inoculation with TMV (d)

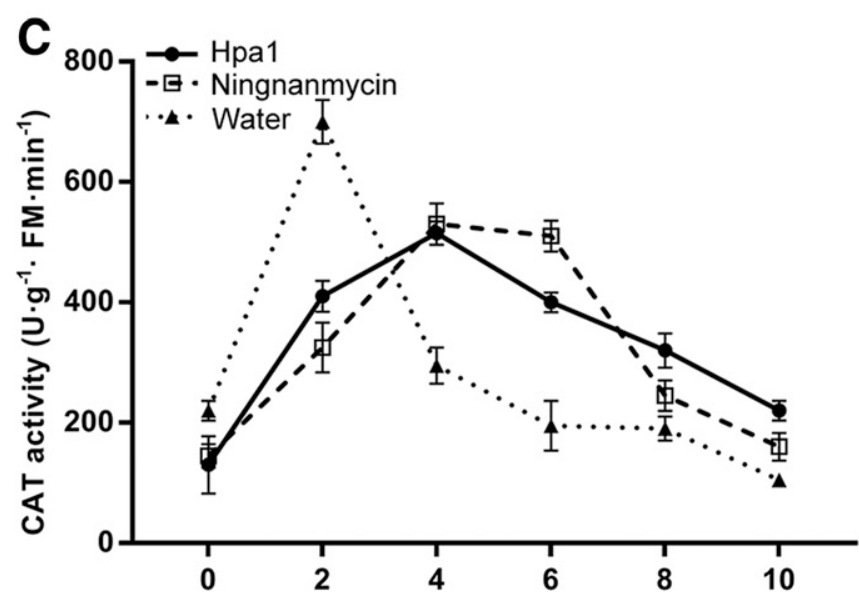

Time after inoculation with TMV (d)

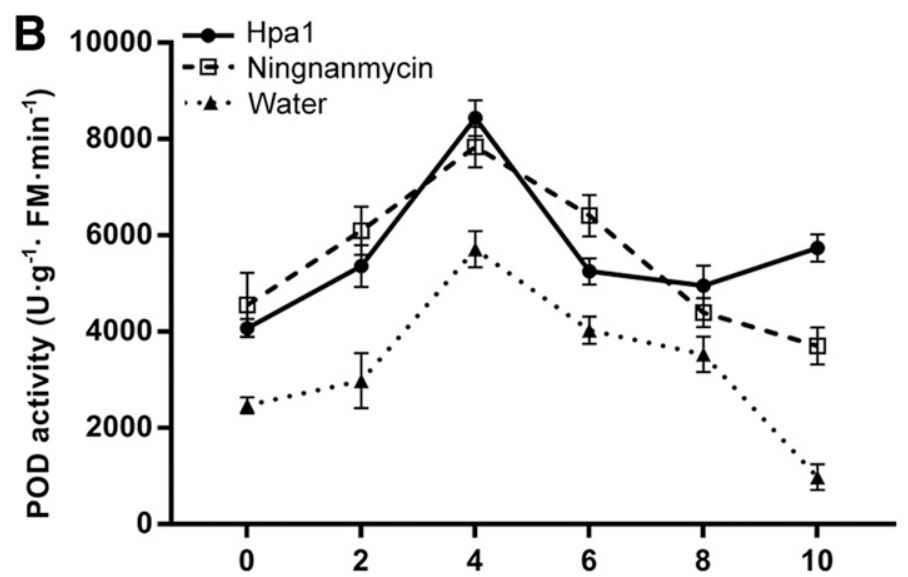

Time after inoculation with TMV (d)

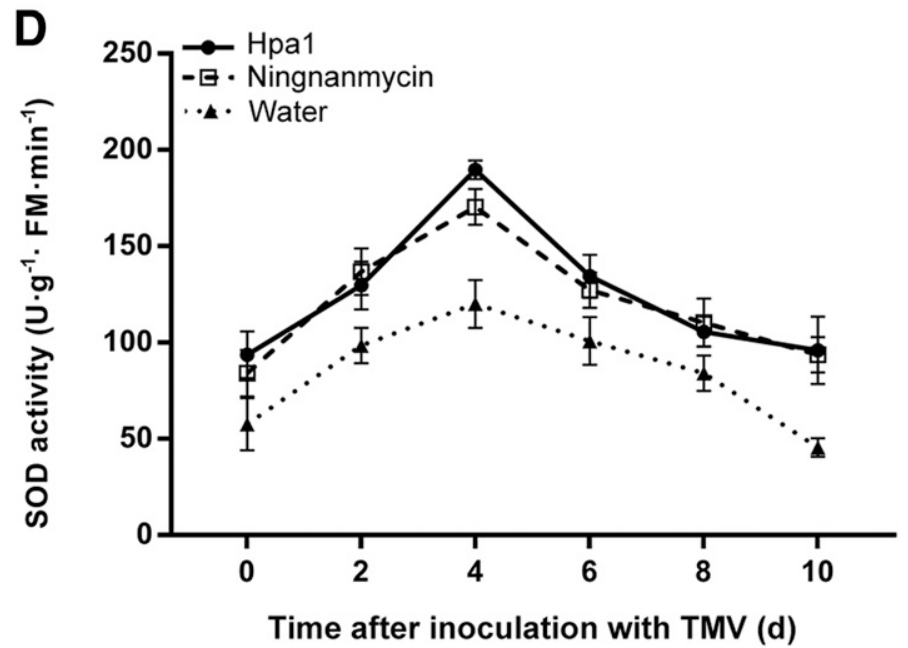

Fig. 1. Effects of Hpal application on the activities of four defense-related enzymes in Pinellia ternata. A, Activity of the pathogenesis-related defense enzyme polyphenol oxidase (PPO). B, C, and D, Activities of the reactive oxygen species-scavenging enzymes peroxidase (POD), catalase (CAT), and superoxide dismutase (SOD), respectively. The $P$. ternata plants were presprayed with Hpal $\left(15 \mu \mathrm{g} \mathrm{ml}^{-1}\right)$, ningnanmycin $\left(500 \mu \mathrm{g} \mathrm{ml}^{-1}\right)$, and distilled water, and plants were inoculated with tobacco mosaic virus (TMV; $15 \mu \mathrm{g} \mathrm{ml} \mathrm{l}^{-1}$ ) at 1 day postapplication of Hpal, ningnanmycin, or water. The treated leaves were then collected to determine the enzyme activities at $0,2,4,6,8$, and 10 days postinoculation of TMV. Data shown are mean values \pm standard error of the results from four replicates (40 plants per replicate for each treatment). 
The trend in SOD activity was similar to that of the PPO activity (Fig. 1D). The above results indicated that application of Hpal enhanced the accumulation of four defensive enzymes (PPO, POD, CAT, and SOD) to improve the disease resistance of plants.

Effects of Hpa1 on defense-related substance content. MDA is commonly used as an index of membrane lipid peroxidation, and the MDA content reflects the degree of membrane damage or plant injury. The lower the content of MDA, the smaller the degree of membrane lipid peroxidation. The MDA content in Hpa1-pretreated $P$. ternata plants was tested at $0,2,4,6,8$, and 10 dpi and compared with the treatments for ningnanmycin and distilled water. After the application of Hpa1, the MDA content in $P$. ternata increased gradually from 0 to $6 \mathrm{dpi}$ of TMV, reached the highest level at $6 \mathrm{dpi}$, and then decreased gradually during 6 to 10 dpi. However, the MDA content in the Hpa1-treated P. ternata plants was lower than that of distilled water at all time points. These data suggest that Hpal treatment could activate related metabolic pathways to reduce the accumulation of MDA. No difference in the MDA content between Hpal and ningnanmycin treatment was observed (Fig. 2B). $\mathrm{H}_{2} \mathrm{O}_{2}$ is an important type of reactive oxygen species (ROS) involved in an oxidative burst that is thought to be one of the key responses in plant disease resistance (Romero et al. 2008). The $\mathrm{H}_{2} \mathrm{O}_{2}$ content in the Hpa1-treated $P$. ternata plants was measured at $0,3,6,9,12,24,48,72$, and 96 hpi of TMV to examine whether $\mathrm{Hpa} 1$ treatment contributed to $\mathrm{H}_{2} \mathrm{O}_{2}$ bursts. In Figure 2A, spraying with Hpa1 resulted in an oxidative explosion of ROS in the $P$. ternata leaves during the experimental period, which peaked at $24 \mathrm{hpi}$ and then declined gradually thereafter.

The defense responses of Hpal were further studied through histopathological analysis. The accumulation of $\mathrm{H}_{2} \mathrm{O}_{2}$, callose, and phenolics was evaluated at various time points after spraying with Hpa1. Microscope observations showed that the accumulation patterns of $\mathrm{H}_{2} \mathrm{O}_{2}$, callose, and phenolics were the same in the three different treatments, but the initial and peak time of accumulation and the amount of accumulation varied. In Figure $3 \mathrm{~A}$, the accumulation mode of $\mathrm{H}_{2} \mathrm{O}_{2}$ in the form of brown spots was observed at $9 \mathrm{~h}$ post-Hpal treatment. As treatment time was prolonged, $\mathrm{H}_{2} \mathrm{O}_{2}$ accumulation increased with a gradual increase in the area of brown spots up to $24 \mathrm{~h}$ post-Hpa 1 treatment. The patterns of callose and phenolic deposition were similar to that of the $\mathrm{H}_{2} \mathrm{O}_{2}$ accumulation (Fig. 3B and C), these two substances accumulated early, and their degree of accumulation were highest in Hpa1treated $P$. ternata plants.

Expression analysis of pathogenesis-related genes. The effects of different treatment inductions on the expression of $P R l$, $P R 5, P R 3$, and PDF1.2 in P. ternata were assessed using RT-qPCR. The results showed that four defense-related genes were significantly upregulated in Hpa1- or ningnanmycin-treated $P$. ternata samples (Fig. 4). The change in $P R 1$ gene expression after different treatments in the test plants is shown in Figure $4 \mathrm{~A}$. A relatively high level of expression of the $P R I$ gene was detected in the Hpal-treated plants, except at $2 \mathrm{dpi}$. $P R 1$ gene expression also increased sharply between 2 and $4 \mathrm{dpi}$ and peaked at $4 \mathrm{dpi}$ and was 4.3 -fold higher than that of the distilled water-treated plants. The expression of the PR5 gene peaked at 2 dpi in the Hpal-treated plants, and its expression was 2.8-fold higher than that of the control treatment. Its expression decreased thereafter (Fig. 4B). In comparison with the maximum levels of PR5 accumulation in the Hpa1 treatment (on day 2), the peak of $P R 5$ in the ningnanmycin-treated plants was delayed by 2 days (on day 4). Moreover, the expression of $P R 3$ and PDF1.2, which are associated with the jasmonic acid/ethylene (JA/ET) pathway, significantly increased in $P$. ternata with Hpal and ningnanmycin treatment. The expression of the $P R 3$ gene in the Hpa1-treated plants peaked at 6 dpi and exhibited a delay by 2 days compared with that in the ningnanmycin-treated plants (peaked at 4 dpi); this expression was 2.9-fold higher than that of the control group (Fig. 4C). The expression level of PDF1.2 in the Hpa1treated plants accumulated faster and peaked at $2 \mathrm{dpi}$. The expression level of PDF1.2 was 3.05-fold higher in the Hpa1treated plants compared with that of the control (Fig. 4D). Although the expression of resistance-related genes differed between the Hpa1 and ningnanmycin treatments in terms of days required to reach maximum levels of accumulation, the disease resistance levels of the plants in both treatments were similar.

The potential effectiveness of Hpa1 in reducing TMV in the field. Although Hpa1 could induce $P$. ternata resistance in the greenhouse experiments, this finding did not prove that the treatment could trigger disease resistance under field conditions. Thus, field experiments were conducted to further confirm the disease control effect of Hpal against TMV infection in P. ternata. The plants were treated with Hpal $\left(15 \mu \mathrm{g} \mathrm{ml}^{-1}\right)$ or distilled water prior to inoculation with TMV $\left(15 \mu \mathrm{g} \mathrm{ml}^{-1}\right)$ at 2, 4, 8, and $10 \mathrm{dpa}$ of Hpa1 or water. Firstly, plants were analyzed at 3 weeks
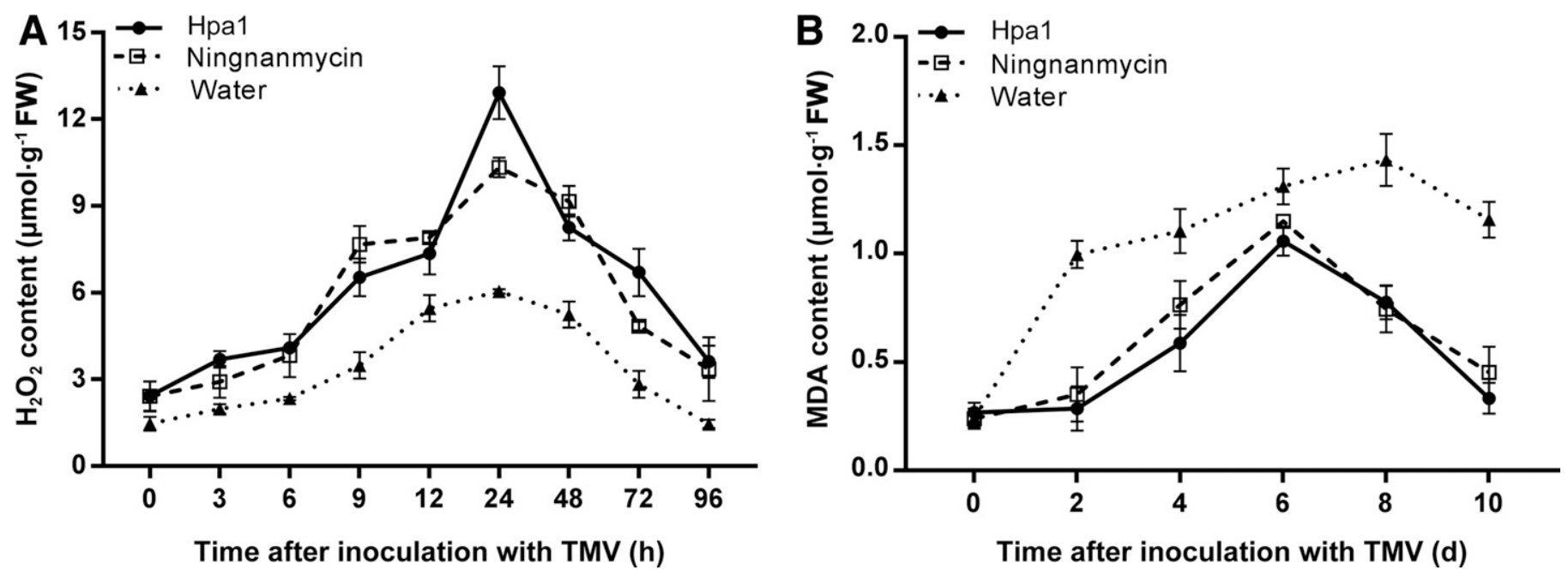

Fig. 2. Effect of Hpal application on A, hydrogen peroxide $\left(\mathrm{H}_{2} \mathrm{O}_{2}\right)$ and $\mathbf{B}$, malondialdehyde (MDA) contents in Pinellia ternata. The P. ternata plants were presprayed with Hpal $\left(15 \mu \mathrm{g} \mathrm{ml}^{-1}\right)$, ningnanmycin $\left(500 \mu \mathrm{g} \mathrm{ml}^{-1}\right)$, and distilled water. Tobacco mosaic virus (TMV; $\left.15 \mu \mathrm{g} \mathrm{ml}{ }^{-1}\right)$ was inoculated onto plants at 1 day postapplication of Hpal, ningnanmycin, or water. The treated leaves were then collected to detect the content changes of MDA at $0,2,4,6,8$, and 10 days postinoculation of TMV, and the level changes of $\mathrm{H}_{2} \mathrm{O}_{2}$ at $0,3,6,9,12,24,48,72$, and $96 \mathrm{~h}$ postinoculation of TMV, respectively. Data shown are mean values \pm standard error of the results from four replicates (40 plants per replicate for each treatment). 
postinoculation with TMV for TMV-CP gene expression using RT-qPCR. The results indicated that Hpa1-treated leaves $(15 \mu \mathrm{g}$ $\mathrm{ml}^{-1}$ ) significantly inhibited TMV multiplication at $2 \mathrm{dpa}$ of Hpa1 $(P<0.05)$. The level of TMV-CP transcripts in the Hpa1treated leaves at 2 dpa was approximately 11.52 -fold lower than that in the control (Fig. 5). The interval time between Hpa1 treatment and TMV inoculation was 10 days, the effect of Hpa1 on TMV CP transcript accumulation was the lowest. These data suggest that the effect of Hpal treatment was decreased with increase in time interval between the Hpal application and TMV inoculation. However, some induction of resistance was observed in Hpa1-treated plants compared with that of the control, indicating that the Hpa1-induced resistance of $P$. ternata to TMV might last approximately 10 days (Fig. 5). Therefore, these results suggest that Hpal treatment provided resistance to TMV under field conditions, most likely through systemic acquired resistance.

Secondly, the disease severity was evaluated using the criterion disease index, which was determined based on the levels of plant infection. As shown in Table 3 and Figure 6, the disease indices significantly differed among the various treatments. When TMV was inoculated at 2 dpa of Hpa1, $P$. ternata showed mild or no disease symptoms, as the average disease severity of 50 repetitions was $8.6 \%$, while that of the control (water inoculated) was as high as $85 \%$. When TMV was inoculated at 4 dpa of Hpa1, the susceptibility level was mostly distributed within disease scale 1 , in which the incidence was higher than that of the 2 dpa of Hpa1. The difference in disease severity and control efficiency between 2 and 4 dpa of Hpal was not significant $(P>0.05)$. The control efficiency of TMV inoculation at 8 and $10 \mathrm{dpa}$ of Hpal (63.9 and $48.7 \%$, respectively) was slightly worse than that of the first two (2 and $4 \mathrm{dpa}$ ) treatments ( 85.0 and $80.1 \%$, respectively), and mild mosaic symptoms were observed. However, the average disease severity in the water-treated control was higher in TMV inoculation from 2 to $10 \mathrm{dpa}$ of water, and severe mosaic symptoms were observed. The disease evaluation results were correlated with the levels of TMV-CP transcripts, indicating that the 2-day interval favored increased resistance to TMV by Hpa1, and Hpal-induced resistance had a protective duration of 10 days.

\section{DISCUSSION}

Plant viral diseases are difficult to control, and their impact on agricultural production causes considerable economic losses worldwide. Microorganisms are an important resource for the development of antivirus agents. At present, some specific broadspectrum defense response elicitors, identified and screened from microbial metabolites, have been widely explored (Han et al. 2014; Su et al. 2017; Wang et al. 2013a, b; Zhang et al. 2016). For example, harpin proteins, isolated from Gram-negative plant pathogenic bacteria, are a class of multifunctional substances that can induce plant growth and activate a series of plant defense responses to resist pathogens (Chen et al. 2008a, b; Liu et al. 2006; Peng et al. 2004; Wu et al. 2007; Zhang et al. 2007, 2011). Hpa1 is a harpin protein produced by the rice bacterial leaf streak pathogen (Li et al. 2004; Liu et al. 2006), which can promote plant growth and improve plant disease and stress resistance. Some studies have shown that transgenic wheat expressing Hpa1 demonstrated resistance to powdery mildew, scab, and wheat aphid (Fu et al. 2014; Li et al. 2014; Wang et al. 2014). In addition, Hpal can also induce plant resistance to pathogens, including viruses (Chen et al. 2008a; Sang et al. 2012), by exogenous application. Moreover, the Hpa1 protein could be easily and rapidly obtained in large quantities by prokaryotic expression, offering a defined production system and a continuous supply of products with uniform quality and yield. Additionally, Hpal can be extracted easily and purified efficiently at fairly low cost, making the industrialized production feasible. Therefore, Hpa1 has great application potential in crop protection against pathogens.

Although our previous studies have shown that Hpal has good antiviral effects (Peng et al. 2004), the mechanism of disease resistance and the field applicability of Hpal remain unclear. Therefore, the potential mechanism of Hpal in enhancing TMV resistance in P. ternata and the effectiveness of the field application of Hpal were systematically analyzed in this study by assessing defense enzyme activity, defense-related substance contents, and defense-related gene expression, and by histopathological observation. Our antiviral activity results showed that $15 \mu \mathrm{g} \mathrm{ml}^{-1} \mathrm{Hpa} 1$ had a strong inhibitory effect on TMV. The induction ability of these molecules is concentration dependent (Baker et al. 1997). However, high concentrations may destroy plant cell tissues, thereby
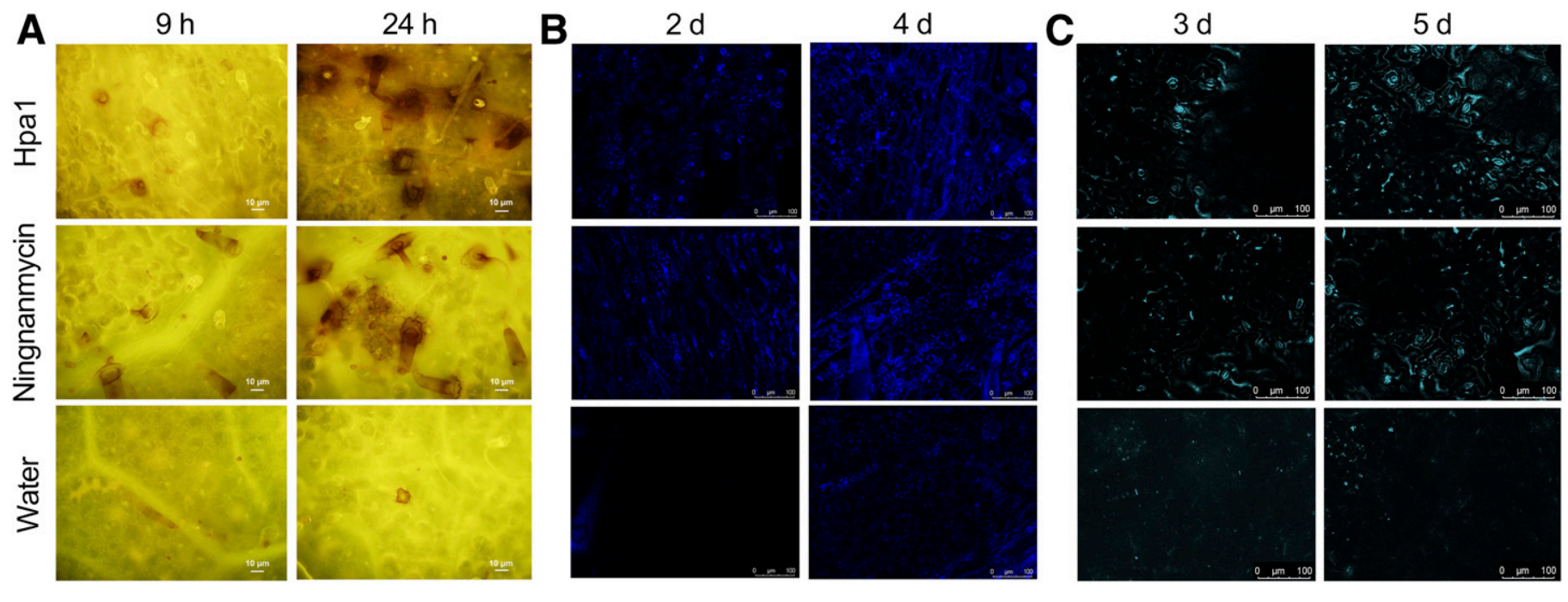

Fig. 3. Comparison of the defense responses in Pinellia ternata pretreated with Hpa1, ningnanmycin, and distilled water through histopathological analysis. The $P$. ternata plants were presprayed with Hpal $\left(15 \mu \mathrm{g} \mathrm{ml} l^{-1}\right)$, ningnanmycin $\left(500 \mu \mathrm{g} \mathrm{ml}{ }^{-1}\right)$, and distilled water, and tobacco mosaic virus $\left(\mathrm{TMV}\right.$; $\left.15 \mu \mathrm{g} \mathrm{ml} l^{-1}\right)$ was inoculated onto leaves at 1 day postapplication of Hpal, ningnanmycin, or water. The accumulation of $\mathrm{H}_{2} \mathrm{O}_{2}$ and the deposition of callose and phenolic compounds on noninoculated leaves were observed at $0,3,6,9,12,24,48,72$, and $96 \mathrm{~h}$ postinoculation (hpi) with TMV and at $0,1,2,3,4,5,6,7$, and 8 days postinoculation (dpi) of TMV, respectively. A, $\mathrm{H}_{2} \mathrm{O}_{2}$ accumulation in the noninoculated leaves at 9 and 24 hpi of TMV. Bars $=10 \mu \mathrm{m}$. B, Callose deposition on noninoculated leaves at 2 and 4 dpi of TMV. Bars $=20 \mu \mathrm{m}$. C, Phenolic autofluorogen accumulation at the infection sites of the mesophyll cells at 3 and 5 dpi of TMV. Bars $=$ $20 \mu \mathrm{m}$. There were three replicates for every treatment ( 30 plants per replicate). 
inhibiting the activation of other disease-resistant pathways and reducing plant resistance. In this study, the lower concentration of Hpal was associated with reduced resistance activity, whereas resistance was enhanced with increased concentration, although this relationship began to decline slightly after $15 \mu \mathrm{g} \mathrm{ml}^{-1}$ (Table 2). These data suggest that Hpa1 elicits resistance in P. ternate against TMV in a dose-dependent manner up to $15 \mu \mathrm{g} \mathrm{ml}{ }^{-1}$.

The enhanced disease resistance of $P$. ternata was closely correlated with the increase in defense enzyme activity and content of defense-related substances. ROS outbreak is one of the defense responses of plants to pathogens. When plants are under stress, their original equilibrium state is disrupted, resulting in excessive ROS production and stimulation of plant disease resistance (Romero et al. 2008). $\mathrm{H}_{2} \mathrm{O}_{2}$ is a type of ROS that plays a dual role in plants; low $\mathrm{H}_{2} \mathrm{O}_{2}$ concentrations can stimulate the expression of defense genes, while high $\mathrm{H}_{2} \mathrm{O}_{2}$ concentrations can induce cell death and limit the growth of pathogens (Pastori and Foyer 2002). In this study, as shown in Figures $2 \mathrm{~A}$ and $3 \mathrm{~A}, \mathrm{H}_{2} \mathrm{O}_{2}$ was produced at higher levels in the Hpa1-treated plants than the control plants. To protect cells against ROS, plants have developed a complex antioxidative defense system comprising antioxidative enzymes, such as SOD,
CAT, and POD. These defense systems are the main components of the ROS scavenging system that can reduce the damage of ROS to cell membranes in plants (Mullineaux and Baker 2010). In this study, the POD and SOD activities in the Hpa1-treated plants were significantly higher than those of the control plants at every time point during the course of the experiment, although they peaked at different time points. One possible explanation for this observation is that different antioxidative enzymes in $P$. ternata play their respective roles at different stages. However, during the first 2 days upon inoculation with TMV, the CAT activity of the Hpa1-treated plants was significantly lower than that of the control plants, mainly because the virus colonizes living plant tissues and obtains nutrients from living host cells. The lower CAT activity, weaker ROS scavenging ability, and greater toxicity to the cells contributed to reduced TMV replication easily (Fig. 1C).

Moreover, $\mathrm{H}_{2} \mathrm{O}_{2}$ can also favor callose accumulation to enhance cell wall strength. Callose deposition is considered a physical barrier at the early stage of pathogenic bacterial infection and helps protect the cell wall against pathogen infection (Luna et al. 2011). In this study, histopathological observation showed that the accumulation of callose was higher than the control after Hpa1 induction
A

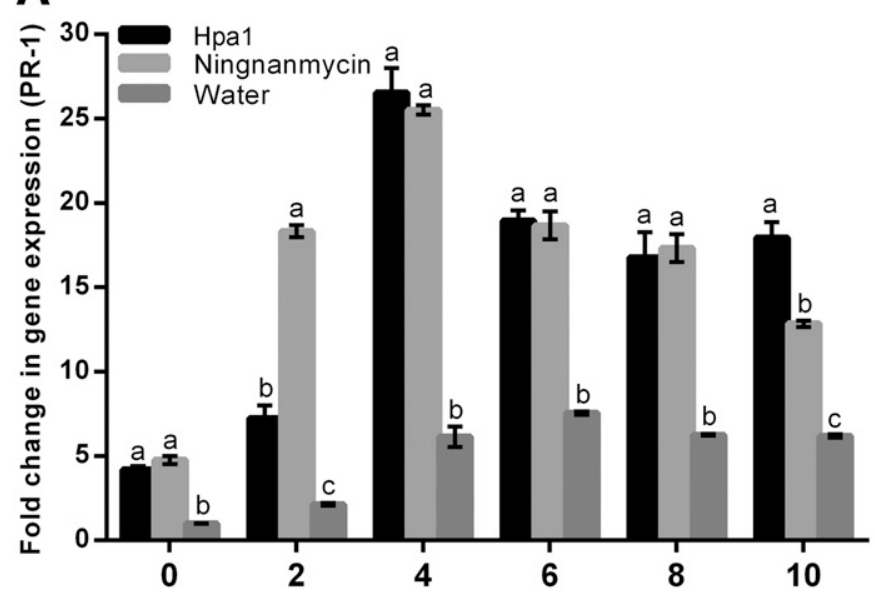

C

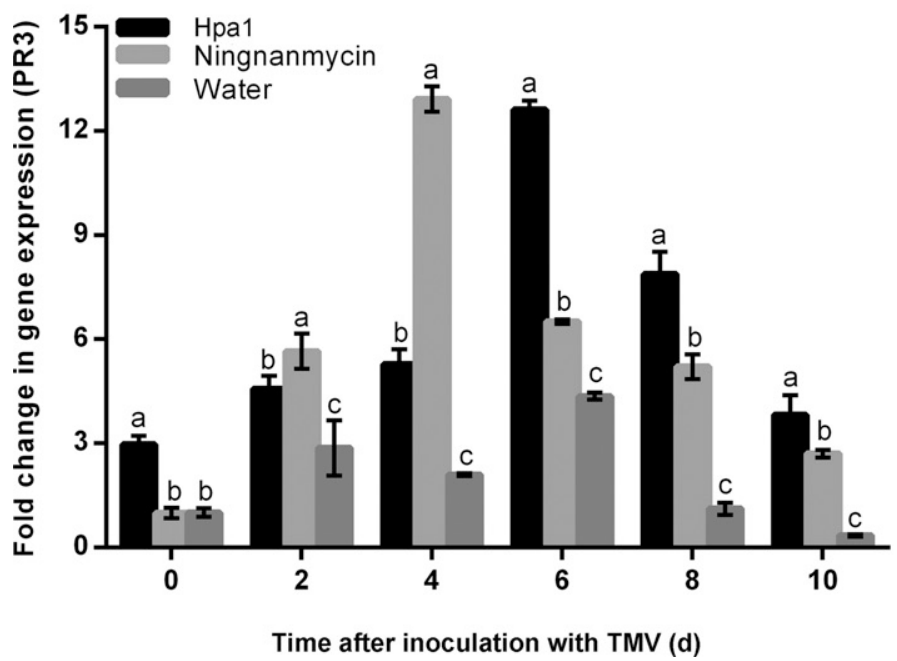

B

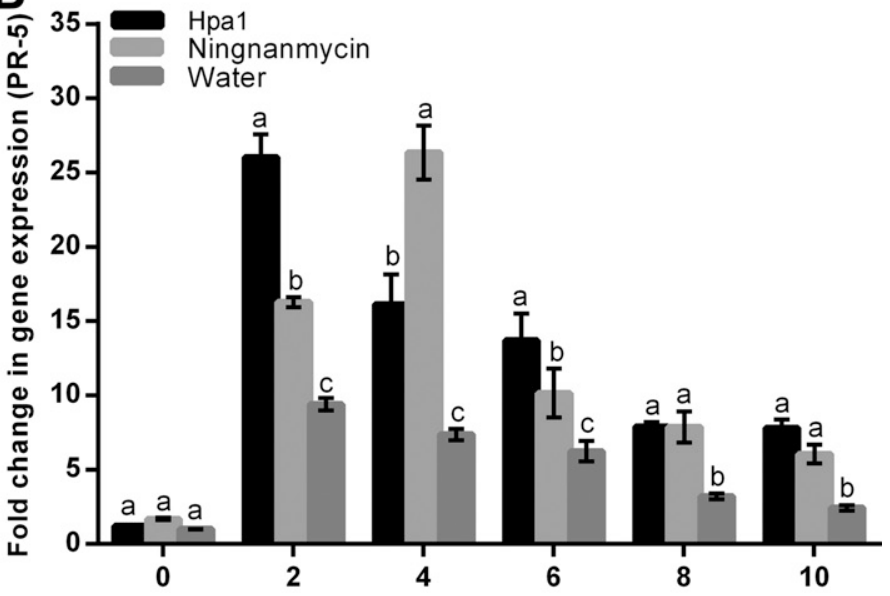

Time after inoculation with TMV (d)

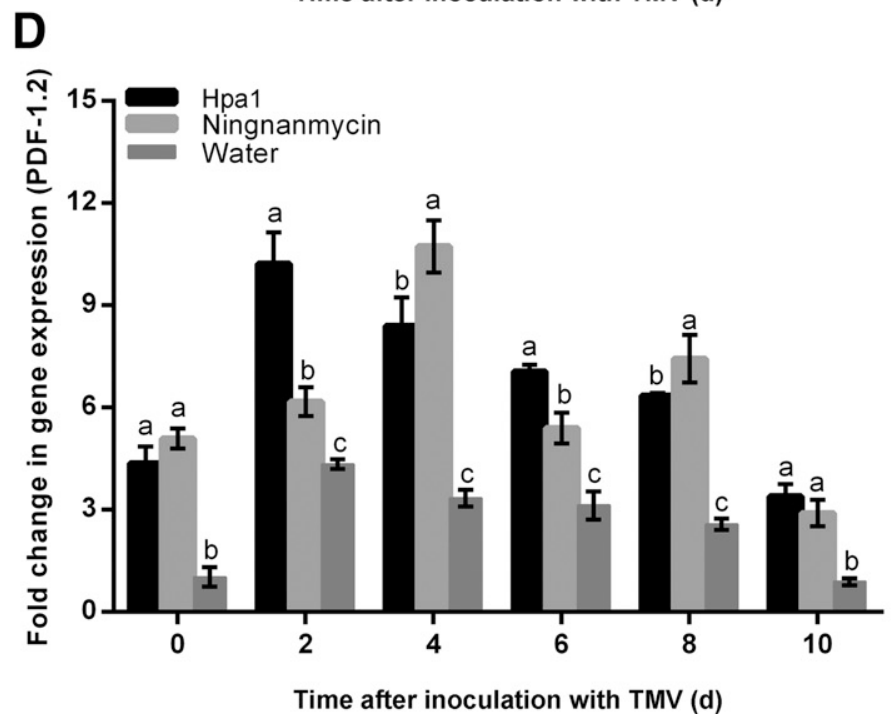

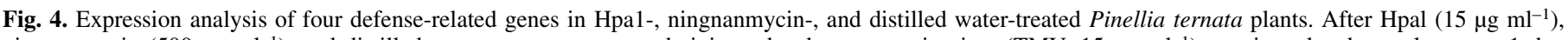

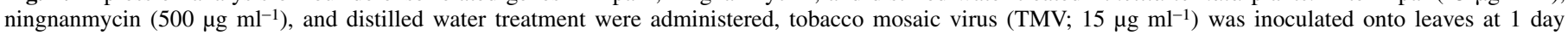

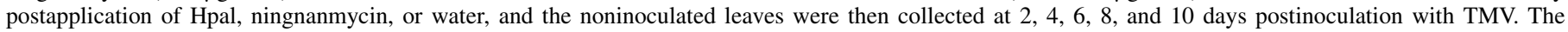

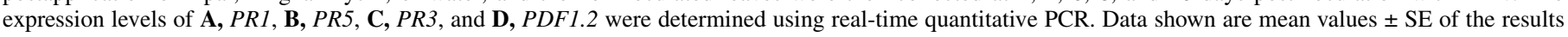

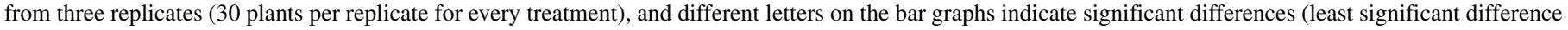
test at $P<0.01)$. 


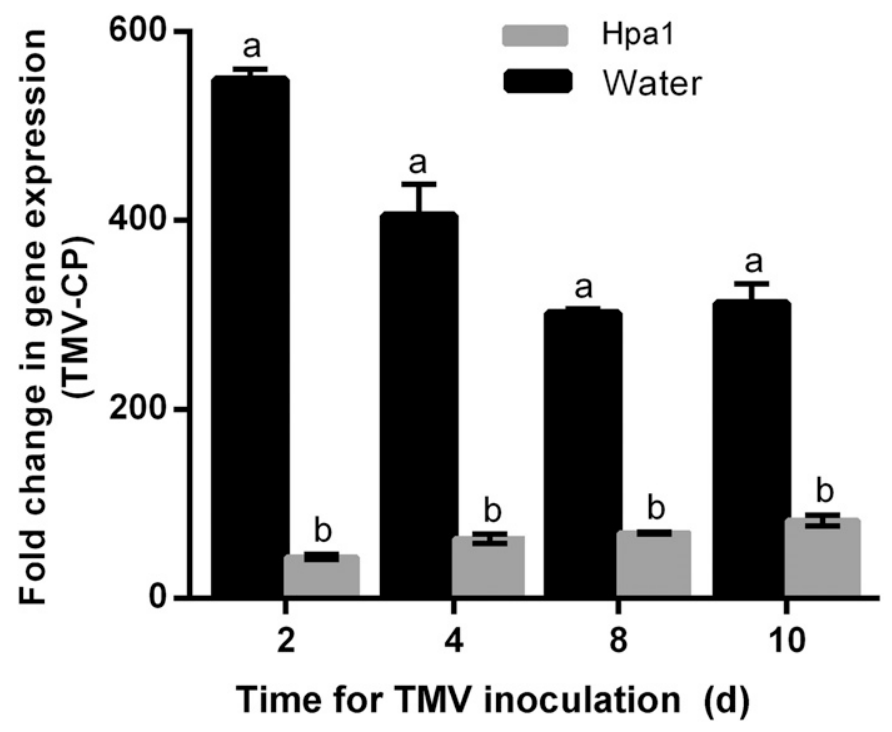

Fig. 5. Time course accumulation of tobacco mosaic virus (TMV)-CP transcripts in Hpa1-pretreated Pinellia ternata plants inoculated with TMV. The plants were treated with Hpal $\left(15 \mu \mathrm{g} \mathrm{ml}^{-1}\right)$ or distilled water prior to inoculation with TMV. TMV $\left(15 \mu \mathrm{g} \mathrm{ml}^{-1}\right)$ was inoculated onto the leaves at 2, 4, 8 , and 10 days postapplication of Hpa1 or water. Plants were analyzed at 3 weeks postinoculation with TMV for TMV-CP gene expression using realtime quantitative PCR. Data shown are mean values \pm SE of the results from three replicates (30 plants per replicate for every treatment), and different letters on the bar graphs indicate significant differences (least significant difference test at $P<0.01$ ).
(Fig. 3B). PPO is one of the key enzymes in the synthesis of phenylalanine compounds. Its intermediate products, such as phenolic substances, are closely related to plant disease resistance. PPO can oxidize phenolic substances into quinones, which are harmful to pathogens (Mohammadi and Kazemi 2002). In this study, Hpa1-treated P. ternata accumulated more PPO and phenolic substances than the control (Figs. 1A and 3C). MDA is used as a marker to reflect the degree of damage to plant cell membranes. The lower the MDA content, the stronger the disease resistance of plants. We found that the MDA content in Hpa1-treated plants was lower than the control (Fig. 2B), suggesting that Hpa1 significantly enhanced the defense resistance activity.

Plant immune responses are produced by three hormone signaling networks, namely SA, JA, and ET, which are closely related to disease resistance (Dong 1998). After inoculation with TMV, the expression levels of the $P R l$ and $P R 5$ genes in the Hpa1treated plants were higher than those in the plants treated with water (Fig. 4A and B). These genes are important in SA resistance pathway and are key to mediating the SA pathway for the initiation of systemic acquired resistance (SAR) (Edreva 2005; Van Loon et al. 2006). SAR is associated with the coordinated upregulation of specific genome-encoding PR proteins, which likely contribute to disease resistance (Xiao et al. 2003). Thus, in the present study, Hpa1 might induce SAR, which might be mediated by the SA pathway in $P$. ternata. Detection of the $P R 3$ gene in the JA signaling pathway and the cross-regulatory factor $P D F 1.2$ gene of JA/ET showed that Hpal treatment could activate ET and JA signals more strongly than water treatment (Fig. 4C and D). Therefore, the JA/ET signaling pathway might be an important

TABLE 3. Disease incidence of Hpa1-pretreated Pinellia ternata plants inoculated with tobacco mosaic virus (TMV) at different interval times ${ }^{\text {a }}$

\begin{tabular}{|c|c|c|c|c|}
\hline Treatment & Interval time (day) & Disease severity (\%) & Control efficiency (\%) & Resistance \\
\hline \multirow[t]{4}{*}{ Hpa1 } & 2 & 8.6 & 85.0 & $\mathrm{R}$ \\
\hline & 4 & 12.5 & 80.1 & $\mathrm{R}$ \\
\hline & 8 & 26.5 & 63.9 & MR \\
\hline & 10 & 38.5 & 48.7 & MR \\
\hline
\end{tabular}

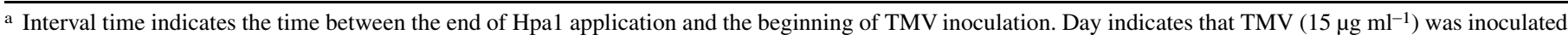
onto the leaves of $P$. ternata plants at 2, 4, 8, and 10 days postapplication by Hpa1 $\left(15 \mu \mathrm{g} \mathrm{ml} \mathrm{m}^{-1}\right)$, respectively. The disease incidence of each leaf was investigated after 3 weeks of TMV inoculation. Disease severity and biocontrol efficacy were calculated using the following formulas: Disease severity $=[\Sigma$ (number of diseased plants in this index $\times$ disease index $) /($ total number of plants investigated $\times$ the highest disease index $)] \times 100 \%$; Control efficiency $=[($ disease severity in the control group - disease severity in the treatment group)/(disease severity in the control group)] $\times 100 \%$. The classification criteria of resistance were implemented in accordance with national industry standards (YC/T39 1996): resistance (R), 0 to 25.0; moderate resistance (MR), 25.1 to 50.0; moderate susceptibility, 50.1 to 75.0 ; and susceptibility, 75.1 to 100 .

Day 2

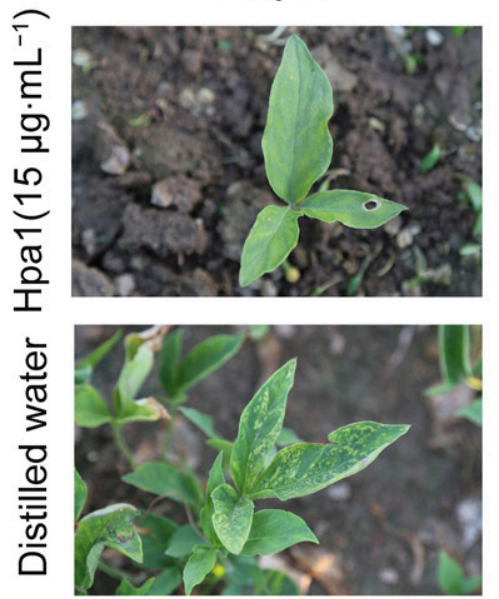

Day 4
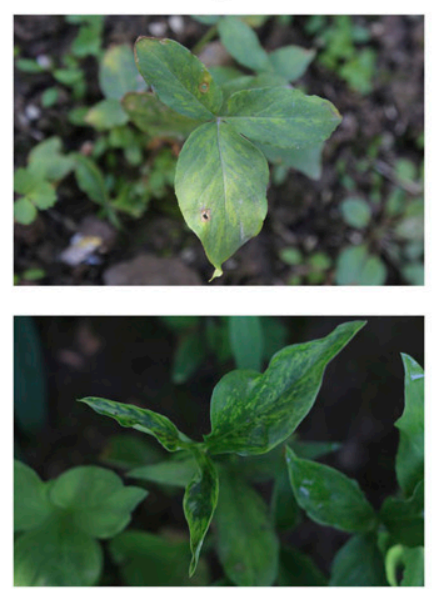

Day 8
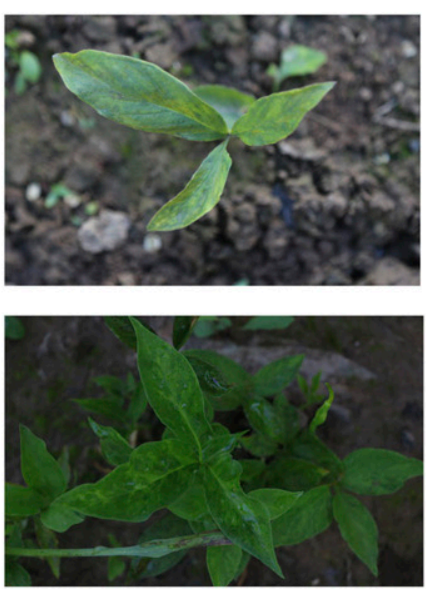

Day 10
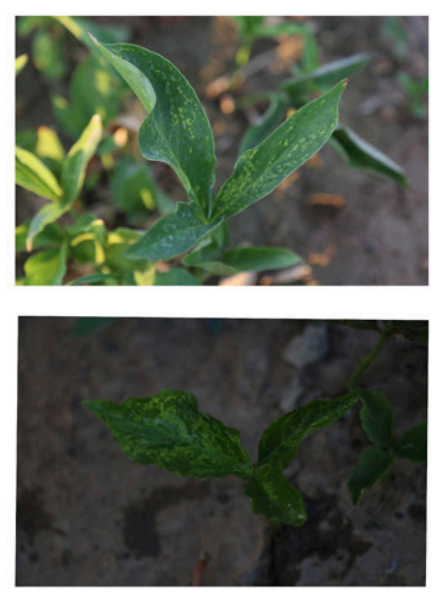

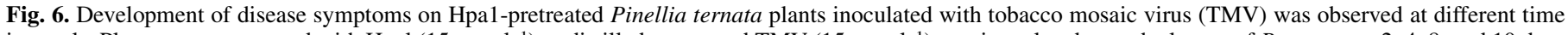

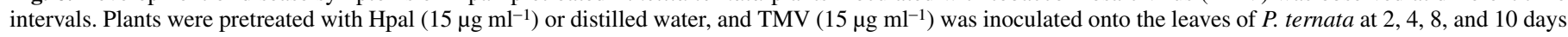

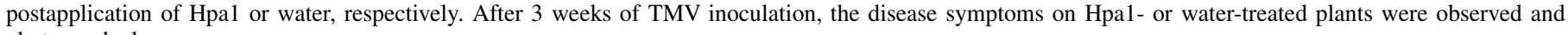
photographed. 
pathway for inducing disease resistance in $P$. ternata by exogenous application of Hpa1. However, the synergistic effects of different defense pathways leading to the cumulative effect on the TMV resistance level remain unclear. Further studies are needed to determine such effects.

In conclusion, Hpa1 exhibited potential antiviral activity against TMV. This inhibitory effect might be attributed to the activation of plant systemic resistance in the form of increased PPO, POD, CAT, and SOD activity, decreased MDA content, accumulation of $\mathrm{H}_{2} \mathrm{O}_{2}$, callose, and phenolics, and the strong expression of $P R$ genes. Although treatment with Hpal significantly enhanced disease resistance, the efficacy of its field application in preventing TMV and the overall impact of viral infection on the quality and yield of plants should be further studied using additional experiments and field trials. Fortunately, Hpa1 has moderate antiviral activity, and its effect is similar to that of the commercial drug ningnanmycin. Furthermore, Hpal can be extracted easily and purified efficiently at fairly low cost, making industrialized production feasible. Most importantly, Hpa1 is easily biodegradable and ecofriendly and is thus a potential antiviral agent suitable for agricultural applications.

\section{ACKNOWLEDGMENTS}

We thank Hansong Dong (Nanjing Agriculture University, Nanjing, China) for gifting the Hpa1 protein used in this study.

\section{LITERATURE CITED}

Aebi, H. 1984. Catalase in vitro. Methods Enzymol. 105:121-126.

Alfano, J. R., and Collmer, A. 2004. Type III secretion system effector proteins: Double agents in bacterial disease and plant defense. Annu. Rev. Phytopathol. 42:385-414.

Baker, B., Zambryski, P., Staskawicz, B., and Dinesh-Kumar, S. P. 1997. Signaling in plant-microbe interactions. Science 276:726-733.

Chen, L., Qian, J., Qu, S., Long, J., Yin, Q., Zhang, C., Wu, T., Sun, F., Wu, T., Hayes, M., Beer, S. V., and Dong, H. 2008a. Identification of specific fragments of $\mathrm{HpaG}_{\text {Xooc }}$, a harpin protein from Xanthomonas oryzae $\mathrm{pv}$. oryzicola, that induce disease resistance and enhanced growth in rice. Phytopathology 98:781-791.

Chen, L., Zhang, S., Zhang, S., Qu, S., Ren, X., Long, J., Yin, Q., Qian, J., Sun, F., Zhang, C., Wang, L., Wu, X., Wu, T., Zhang, Z., Cheng, Z., Hayes, M., Beer, S., and Dong, H. 2008b. A fragment of the Xanthomonas oryzae pv. oryzicola harpin $\mathrm{HpaG}_{\text {Xooc }}$ reduces disease and increases yield of rice in extensive grower plantings. Phytopathology 98:792-802.

Dangl, J. L., Dietrich, R. A., and Richberg, M. H. 1996. Death don't have no mercy: cell death programs in plant-microbe interactions. Plant Cell 8: 1793-1807.

Dodds, P. N., and Rathjen, J. P. 2010. Plant immunity: Towards an integrated view of plant-pathogen interactions. Nat. Rev. Genet. 11:539-548.

Dong, H., Delaney, T. P., Bauer, D. W., and Beer, S. V. 1999. Harpin induces disease resistance in Arabidopsis through the systemic acquired resistance pathway mediated by salicylic acid and the NIM1 gene. Plant J. 20: 207-215.

Dong, X. 1998. SA, JA, ethylene, and disease resistance in plants. Curr. Opin. Plant Biol. 1:316-323.

Durrant, W. E., and Dong, X. 2004. Systemic acquired resistance. Annu. Rev. Phytopathol. 42:185-209.

Edreva, A. 2005. Pathogenesis related proteins: Research progress in the last 15 years. Gen. Appl. Plant Physiol. 31:105-124.

Fan, H., Song, B., Bhadury, P. S., Jin, L., Hu, D., and Yang, S. 2011. Antiviral activity and mechanism of action of novel thiourea containing chiral phosphonate on Tobacco mosaic virus. Int. J. Mol. Sci. 12:4522-4535.

Fu, M., Xu, M., Zhou, T., Wang, D., Tian, S., Han, L., Dong, H., and Zhang, C. 2014. Transgenic expression of a functional fragment of harpin protein Hpa1 in wheat induces the phloem-based defence against English grain aphid. J. Exp. Bot. 65:1439-1453.

Gooding, G. V., Jr., and Hebert, T. T. 1967. A simple technique for purification of tobacco mosaic virus in large quantities. Phytopathology 57:1285.

Han, Y., Luo, Y., Qin, S., Xi, L., Wan, B., and Du, L. 2014. Induction of systemic resistance against tobacco mosaic virus by ningnanmycin in tobacco. Pestic. Biochem. Physiol. 1111:14-18.

He, S., Huang, H., and Collmer, A. 1993. Pseudomonas syringae pv. syringae harpin ${ }_{\text {Pss: }}$ : A protein that is secreted via the Hrp pathway and elicits the hypersensitive response in plants. Cell 73:1255-1266.
Huo, R., Wang, Y., Ma, L., Qiao, J., Shao, M., and Gao, X. 2010. Assessment of inheritance pattern and agronomic performance of transgenic rapeseed having harpin Xooc encoding $h r f 2$ gene. Transgenic Res. 19:841-847.

Jang, Y., Sohn, S. I., and Wang, M. 2006. The hrpN gene of Erwinia amylovora stimulates tobacco growth and enhances resistance to Botrytis cinerea. Planta 223:449-456.

Kim, J. F., and Beer, S. V. 2000. Hrp genes and harpins of Erwinia amylovora: A decade of discovery. Pages 141-161 in: Fire Blight and its Causative Agent, Erwinia amylovora. J. L. Vanneste, ed. CAB International, Wallingford, UK.

Kim, J. G., Park, B. K., Yoo, C. H., Jeon, E., Oh, J., and Hwang, I. 2003. Characterization of the Xanthomonas axonopodis pv. glycines HpaG pathogenicity island. J. Bacteriol. 185:3155-3166.

Li, J., Cao, J., Sun, F., Niu, D., Yan, F., Liu, H., and Guo, J. 2011. Control of Tobacco mosaic virus by PopW as a result of induced resistance in tobacco under greenhouse and field conditions. Phytopathology 101: 1202-1208.

Li, P., Lu, X., Shao, M., Long, J., and Wang, J. 2004. Genetic diversity of harpins from Xanthomonas oryzae and their activity to induce hypersensitive response and disease resistance in tobacco. Sci. China C Life Sci. 47: 461-469.

Li, X., Wang, X., Wang, D., Tian, S., Dong, H., and Zhang, C. 2014. Transgenic expression of an active fragment of the harpin protein Hpal in wheat reduces Fusarium head blight. Acta Phytophylac. Sin. 41:26-34.

Liu, F., Liu, H., Jia, Q., Wu, X., Guo, X., and Zhang, S. 2006. The internal glycine-rich motif and cysteine suppress several effects of the $\mathrm{HpaG}_{X o o c}$ protein in plants. Phytopathology 96:1052-1059.

Livak, K. J., and Schmittgen, T. D. 2001. Analysis of relative gene expression data using real-time quantitative PCR and the $2^{-\triangle \Delta C T}$ method. Methods 25: 402-408.

Lü, B., Sun, W., Zhang, S., Zhang, C., Qian, J., Wang, X., Gao, R., and Dong, H. 2011. $\mathrm{HrpN}_{E a}$-induced deterrent effect on phloem feeding of the green peach aphid Myzus persicae requires AtGSL5 and AtMYB44 genes in Arabidopsis thaliana. J. Biosci. 36:123-137.

Luna, E., Pastor, V., Robert, J., Flors, V., Mauch-Mani, B., and Ton, J. 2011. Callose deposition: A multifaceted plant defense response. Mol. PlantMicrobe Interact. 24:183-193.

Mohammadi, M., and Kazemi, H. 2002. Changes in peroxidase and polyphenol oxidase activities in susceptible and resistant wheat heads inoculated with Fusarium graminearum and induced resistance. Plant Sci. 162: 491-498.

Mullineaux, P. M., and Baker, N. R. 2010. Oxidative stress: Antagonistic signaling for acclimation or cell death? Plant Physiol. 154:521-525.

Pastori, G. M., and Foyer, C. H. 2002. Common components, networks, and pathways of cross-tolerance to stress. The central role of "redox" and abscisic acid-mediated controls. Plant Physiol. 129:460-468.

Peng, J. L., Bao, Z., Ren, H., Wang, J., and Dong, H. 2004. Expression of harpin ${ }_{X o o}$ in transgenic tobacco induces pathogen defense in the absence of hypersensitive response. Phytopathology 94:1048-1055.

Ren, H., Gu, G., Long, J., Yin, Q., Wu, T., Song, T., Zhang, S., Chen, Z., and Dong, H. 2006a. Combinative effects of a bacterial type-III effector and a biocontrol bacterium on rice growth and disease resistance. J. Biosci. 31: 617-627.

Ren, H., Song, T., Wu, T., Sun, L., Liu, Y., Yang, F., Chen, Z., and Dong, H. 2006b. Effects of biocontrol bacterium on growth and defence of transgenic rice plants expressing a bacterial type-III effector. Ann. Microbiol. 56: 281-287.

Romero, D., Eugenia, R. M., Cazorla, F. M., Codina, J. C., Fernández-Ortuñob, D., Torés, J. A., Pérez-Garcíaal, A., and de Vicentea, A. 2008. Comparative histochemical analyses of oxidative burst and cell wall reinforcement in compatible and incompatible melon-powdery mildew (Podosphaera fusca) interactions. J. Plant Physiol. 165:1895-1905.

Ryals, J. A., Neuenschwander, U. H., Willits, M. G., Molina, A., Steiner, H. Y., and Hunt, M. D. 1996. Systemic acquired resistance. Plant Cell 8: 1809-1819.

Sang, S., Li, X., Gao, R., You, Z., Lü, B., Liu, P., Ma, Q., and Dong, H. 2012. Apoplastic and cytoplasmic location of hatpin protein $\mathrm{Hpal}_{x o o}$ plays different roles in $\mathrm{H}_{2} \mathrm{O}_{2}$ generation and pathogen resistance in Arabidopsis. Plant Mol. Biol. 79:375-391.

Shao, M., Wang, J., Dean, R. A., Lin, Y., Gao, X., and Hu, S. 2008. Expression of a harpin-encoding gene in rice confers durable nonspecific resistance to Magnaporthe grisea. Plant Biotechnol. J. 6:73-81.

Sofo, A., Dichio, B., Xiloyannis, C., and Masiab, A. 2004. Effects of different irradiance levels on some antioxidant enzymes and on malondialdehyde content during rewatering in olive tree. Plant Sci. 166:293-302.

Sohn, S. I., Kim, Y. H., Kim, B. R., Lee, S. Y., Lim, C. K., Hur, J. H., and Lee, J. Y. 2007. Transgenic tobacco expressing the $h r p N(E P)$ gene from Erwinia pyrifoliae triggers defense responses against Botrytis cinerea. Mol. Cell 24: 232-239. 
Su, P., Tan, X., Li, C., Zhang, D., Cheng, J., Zhang, S., Zhou, X., Yan, Q., Peng, J., Zhang, Z., Liu, Y., and Lu, X. 2017. Photosynthetic bacterium Rhodopseudomonas palustris GJ-22 induces systemic resistance against viruses. Microb. Biotechnol. 10:612-624.

Tian, S., Fan, Q., Xu, Y., and Jiang, A. 2010. Effects of calcium on biocontrol activity of yeast antagonists against the postharvest fugal pathogen Rhizopus stolonifer. Plant Pathol. 51:352-358.

Van Loon, L. C., Rep, M., and Pieterse, C. M. 2006. Significance of inducible defense-related proteins in infected plants. Annu. Rev. Phytopathol. 44:135-162.

Wang, D., Wang, Y., Fu, M., Mu, S., Han, B., Ji, H., Cai, H., Dong, H., and Zhang, C. 2014. Transgenic expression of the functional fragment Hpa $1_{10-42}$ of the harpin protein Hpal imparts enhanced resistance to powdery mildew in wheat. Plant Dis. 98:448-455.

Wang, G., Wei, X., Fan, R., Zhou, H., Wang, X., Yu, C., Dong, L., Dong, Z., Wang, X., Kang, Z., Ling, Z., Shen, Q., Wang, D., and Zhang, X. 2011. Molecular analysis of common wheat genes encoding three types of cytosolic heat shock protein 90 (Hsp90): Functional involvement of cytosolic Hsp90 in the control of wheat seedling growth and disease resistance. New Phytol. 191:418-431.

Wang, J., Wang, H., Xia, X., Li, P., and Wang, K. 2013a. Inhibitory effect of sulfated lentinan and lentinan against tobacco mosaic virus (TMV) in tobacco seedlings. Int. J. Biol. Macromol. 61:264-269.

Wang, J., Wang, H., Xia, X., Li, P., and Wang, K. 2013b. Inhibitory effect of esterified lactoferin and lactoferin against tobacco mosaic virus in tobacco seedlings. Pestic. Biochem. Physiol. 105:62-68.

Wang, X., Wang, J., Jin, P., and Zheng, Y. 2013. Investigating the efficacy of Bacillus subtilis SM21 on controlling Rhizopus rot in peach fruit. Int. J. Food Microbiol. 164:141-147.

Wei, Z., Laby, R. J., Zumoff, C. H., Bauer, D. W., He, S. Y., Collmer, A., and Beer, S. V. 1992. Harpin, elicitor of the hypersensitive response produced by the plant pathogen Erwinia amylovora. Science 257:85-88.
Wu, X., Wu, T., Long, J., Yin, Q., Zhang, Y., Chen, L., Liu, R., Gao, T., and Dong, H. 2007. Productivity and biochemical properties of green tea in response to full-length and functional fragments of HpaGXooc, a harpin protein from the bacterial rice leaf streak pathogen Xanthomonas oryzae pv. oryzicola. J. Biosci. 32:1119-1131.

Xiao, S., Brown, S., Patrick, E., Brearley, C., and Turner, J. G. 2003. Enhanced transcription of the Arabidopsis disease resistance genes RPW8.1 and $R P W 8.2$ via a salicylic acid-dependent amplification circuit is required for hypersensitive cell death. Plant Cell 15:33-45.

Yu, I., Parker, J., and Bent, A. F. 1998. Gene-for-gene disease resistance without the hypersensitive response in Arabidopsis dnd1 mutant. PNAS 95: 7819-7824.

Zhang, C., Qin, J., Bao, Z., Hong, X., and Dong, H. 2007. the induction of abscisic-acid-mediated drought tolerance is independent of ethylene signaling in Arabidopsis plants responding to a harpin protein. Plant Mol. Biol. Report. 25:98-114.

Zhang, G., Feng, J., Han, L., and Zhang, X. 2016. Antiviral activity of glycoprotein GP-1 isolated from Streptomyces kanasensis ZX01. Int. J. Biol. Macromol. 88:572-577.

Zhang, L., Xiao, S., Li, W., Feng, W., Li, J., Wu, Z., Gao, X., Liu, F., and Shao, M. 2011. Overexpression of a harpin-encoding gene $h r f l$ in rice enhances drought tolerance. J. Exp. Bot. 62:4229-4238.

Zhao, L., Hao, X., and Wu, Y. 2015. Inhibitory effect of polysaccharide peptide (PSP) against Tobacco mosaic virus (TMV). Int. J. Biol. Macromol. 75:474-478.

Zhu, W., Magbanua, M. M., and White, F. F. 2000. Identification of two novel hrp-associated genes in the hrp gene cluster of Xanthomonas oryzae pv. oryzae. J. Bacteriol. 182:1844-1853.

Zuo, J., Mou, J., and Hu, X. 2019. Research progress in the chemical constituents and modern pharmacological effects of Pinellia ternata. J. Liaoning Univ. TCM. 21:26-29. 